Jurnal Kejuruteraan SI 1(3) 2018: 9-14

http://dx.doi.org/10.17576/jkukm-2018-si1(3)-02

\title{
Optimization of Phosphoric Acid-Based Emitter Formation on Silicon Wafer
}

\author{
(Pengoptimuman Pembentukan Pemancar Berasaskan Asid Fosforik ke Atas Wafer Silikon) \\ Zon Fazlila Mohd Ahir, ${ }^{\mathrm{a}, \mathrm{b}, *}$ \\ ${ }^{a}$ Faculty of Technical \& Vocational, Universiti Pendidikan Sultan Idris, Malaysia \\ Suhaila Sepeai ${ }^{\mathrm{b}}$, Saleem H. Zaidi ${ }^{\mathrm{b}}$ \\ ${ }^{b}$ Solar Energy Research Institute, Universiti Kebangsaan Malaysia, Malaysia
}

\begin{abstract}
Crystalline silicon (c-Si) wafer-based solar cells have been dominating the current photovoltaic industries. However, prevalent manufacturing practices are based on environmentally-harmful chemicals and expensive methodologies. This paper reports on the development of inexpensive, environmentally-benign phosphoric acid-based emitter formation methods as an alternative to conventional highly toxic and poisonous $\mathrm{POCl}_{3}$ gas source-based chemistry. Two emitter formation approaches at temperatures in $850-925^{\circ} \mathrm{C}$ range have been investigated. The first approach is referred to as the doctor blade (DB) technique, where the flat $\mathrm{Si}$ wafer surface is uniformly coated by phosphoric acid ( $\mathrm{H}_{3} \mathrm{PO}_{4}$ ) via a moving blade. A small gap between the blade and wafer is maintained in order to form a thin uniform film on the wafer. The second method is referred to as the extension of the blade method (EDB), where an un-doped wafer is placed proximately to the deposited $\mathrm{H}_{3} \mathrm{PO}_{4}$ wafer. During the high temperature drive-in process, phosphorous emitter was formed on the un-doped wafer surface through evaporation and deposition of phosphorus atoms from $\mathrm{H}_{3} \mathrm{PO}_{4}$ coated wafer. All diffusion processes were carried out on $180 \mu \mathrm{m}$ thick, planar boron-doped Si wafers in a conventional quartz tube furnace. The variation of sheet resistances over a broad range from $\sim 20-180 \Omega / s q$ were consistent with temperature dependence. Highest diffusion uniformity was observed for $10 \% \mathrm{H}_{3} \mathrm{PO}_{4}$ solution. Diffusion process simulations based on DifCad software were in good agreement with experimental data. The work reported here illustrates that an environmentally-benign approach in emitter formation based on $\mathrm{H}_{3} \mathrm{PO}_{4}$ is feasible for manufacturing solar cells.
\end{abstract}

Keywords: Efficiency; emitter junction; phosphoric acid; sheet resistance; solar cells

\section{ABSTRAK}

Sel suria berasaskan wafer silikon hablur (c-Si) telah mendominasi industri fotovoltan masa kini. Walau bagaimanapun, amalan pengilangan lazim adalah berdasarkan penggunaan bahan kimia yang berbahaya dan kaedah yang mahal. Kertas kajian ini melaporkan tentang pembangunan kaedah pembentukan pemancar yang murah, mesra alam sekitar berasaskan asid fosforik sebagai alternatifkepada bahan bertoksik dan sumber gas kimia beracun konvensional berasaskan POCl . Dua pendekatan pembentukan pemancar pada julat suhu $850-925^{\circ} \mathrm{C}$ dikaji. Pendekatan pertama merujuk kepada teknik bilah doktor (DB), di mana permukaan rata wafer Si disalut secara seragam oleh asid fosforik $\left(\mathrm{H}_{3} \mathrm{PO}_{4}\right)$ melalui bilah bergerak. Jurang kecil diantara bilah dan wafer dikekalkan bagi membentuk satu filem nipis seragam di atas wafer. Kaedah kedua merujuk kepada teknik bilah doktor lanjutan (EDB) dimana wafer tidak terdop diletakkan berhampiran dengan wafer yang telah dimendapkan dengan filem $\mathrm{H}_{3} \mathrm{PO}_{4}$. Semasa proses pandu masuk bersuhu tinggi, pemancar fosforus terbentuk di atas permukaan wafer tidak terdop melalui penyejatan dan pemendapan atom fosforus dari wafer bersalut $\mathrm{H}_{3} \mathrm{PO}_{4}$. Semua proses peresapan dijalankan ke atas wafer silikon terdop boron berstruktur satah dengan ketebalan 180 um di dalam relau tiub kuarza konvensional. Variasi rintangan keping dalam julat yang besar 20-180 $\Omega /$ sq adalah konsisten dengan kebergantungan suhu. Peresapan seragam tertinggi diperhatikan pada larutan $10 \% \mathrm{H}_{3} \mathrm{PO}_{4}$. Simulasi proses peresapan menggunakan perisian DifCad adalah sepadan dengan data eksperimen. Kajian yang dilaporkan di sini menggambarkan bahawa pendekatan mesra alam sekitar dalam pembentukan pemancar berdasarkan $\mathrm{H}_{3} \mathrm{PO}_{4}$ adalah sesuai untuk pembuatan sel solar.

Kata kunci: Kecekapan;simpang pemancar; asid fosforik; rintangan keping; sel suria

\section{INTRODUCTION}

Emitter formation is the most critical process in solar cell fabrication (Sopian et al. 2017). The emitter formation leads to $p-n$ junction in solar cell (Sakib \& Ahad 2018). The $p-n$ junction is formed when $p$-type semiconductor is placed adjacent to $n$-type semiconductor as shown in Figure 1. When two oppositely charged semiconductor regions are brought together, the carrier concentrations of both $p$ and $n$ region are not initially in equilibrium. To reach equilibrium state, 
the excess electrons in $n$-type semiconductor diffuse across the junction into the $p$-type semiconductor, while the holes in $p$-type semiconductor diffuse to the $n$-type semiconductor. These electron-hole transport processes at $p$ - $n$ interface result in positive region within the $n$-type semiconductor and negative region within the $p$-type material. This $p$ - $n$ region is known as space charge region with a strong electric field $(E)$, across the $p$ - $n$ junction. The formation of the space charge region in a $p-n$ junction with its associated electrical field plays a vital role in the operation of solar cells and is a unique feature of semiconductor.

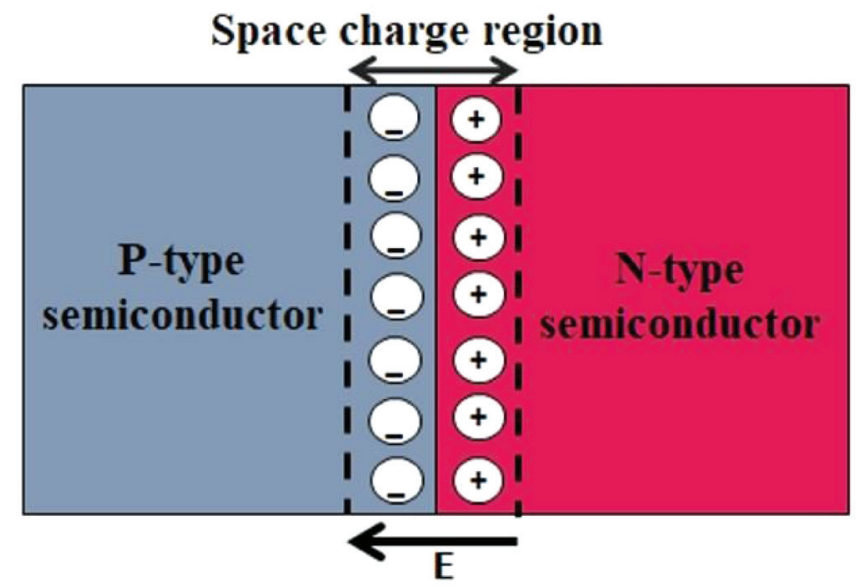

FIGURE 1 . Description of $p$ - $n$ junction, space charge region, and electric field inside semiconductor

Use of a suitable dopant source for emitter formation is an essential requirement in $p$-type crystalline silicon substrate solar cells (Soin \& Majlis 2006). In industrial manufacturing of solar cells, liquid-source based phosphorus oxychloride $\left(\mathrm{POCl}_{3}\right)$ as phosphorous gas source in high temperature quartz tubes is widely used for $n$-type emitter formation on borondoped, $p$-type $\mathrm{Si}$ wafer. The choice of $\mathrm{POCl}_{3}$ as a diffusion source is based on its superior performance in achieving surface passivation and gettering defects. Unless special precautions are implemented, phosphorous is diffused on both sides of Si wafer simultaneously to form an $n-p-n$ structure (Sepeai et al. 2013).

Unfortunately, the use of $\mathrm{POCl}_{3}$ as a dopant source leads to harmful environmental effects due to its extremely high level of toxicity. Therefore, in the interest of environmentfriendliness as well as inexpensive manufacturing, use of phosphoric acid $\left(\mathrm{H}_{3} \mathrm{PO}_{4}\right)$ as the dopant source represents an almost perfect alternative. Several approaches of phosphorus diffusion have been reported including spin-on (Ahmad et al. 2017; Balaji et al. 2015; Moon et al. 2009), ion implantation (Lee et al. 2013; Yang et al. 2015), and spray-on phosphoric acid (Basu et al. 2016). In most of the reported work, use of commercially-manufactured dopants increases costs and places constraints on its shelf-life. In this paper, phosphorus dopant was developed in-house using easily available, inexpensive and nontoxic $\mathrm{H}_{3} \mathrm{PO}_{4}$. This work also reports on $\mathrm{H}_{3} \mathrm{PO}_{4}$ film deposition using a simple approach based on the doctor blade (DB) method.
This report is focused on the characterization of the $\mathrm{H}_{3} \mathrm{PO}_{4}$-based emitter formation with respect to critical experimental parameters including solution concentrations, deposition conditions, and temperatures. Several configurations for emitter layer formation using $\mathrm{H}_{3} \mathrm{PO}_{4}$ were investigated. These experiments were based on controlled variations in concentrations of $\mathrm{H}_{3} \mathrm{PO}_{4}$ four different diffusion temperatures.

Moon et al. (2009) reported that $\mathrm{H}_{3} \mathrm{PO}_{4}$ diluted with deionized (DI) water exhibit non-uniformity over the silicon wafer due to poor surface wettability. This issue was resolved using radio corporation of America (RCA), RCA-2 standard solution to form hydrated surfaces (Ahmad et al. 2017). The DB method investigated in this paper is based on the work reported by Deng et al. (2015) and Kontos et al. (2008) on organic materials for solar cell applications. The extension of DB method to EDB was based on solid source vapour approach (Ramanathan et al. 2011).

In this study, the impact of variation diffusion temperature on variable phosphorus concentration films to form controllable emitters was investigated. Software simulations for emitter profiles were carried out using DifCad to compare with experimental data. In brief, this paper demonstrated feasibility of alternative approach for emitter formation in Si solar cell fabrication process.

\section{METHODOLOGY}

For the experiment work, boron-doped $p$-type crystalline Si wafers in 180-200 $\mu \mathrm{m}$ thickness range at 0.5-3.0 $\Omega-\mathrm{cm}$ resistivity were used as substrates. Figure 2 describes the flow chart for $n^{+}$emitter formation with variation of acid concentrations and diffusion temperatures. As-received wafers were subjected to cleaning and saw damage removal using $10 \%$ sodium hydroxide $(\mathrm{NaOH})$ solution. Subsequently, RCA standard cleaning processes were carried out to remove organic/inorganic contaminations. For coating $\mathrm{H}_{3} \mathrm{PO}_{4}$ films, hydrophilic surfaces were formed in the solution of ammonium hydroxide: hydrogen peroxide: DI water $\left(\mathrm{NH}_{4} \mathrm{OH}\right.$ : $\mathrm{H}_{2} \mathrm{O}_{2}: \mathrm{H}_{2} \mathrm{O}$ ) with a ratio of $1: 1: 5$ by volume at $70^{\circ}$ for 15 minutes. Following the cleaning process, the wafers were divided into eight parts based on $\mathrm{H}_{3} \mathrm{PO}_{4}$ solution concentration for subsequent deposition and high temperature annealing. The variations in $\mathrm{H}_{3} \mathrm{PO}_{4}$ solution concentration were created by mixing acid with controlled quantities of DI water.

In this paper, the $\mathrm{H}_{3} \mathrm{PO}_{4}$ films were coated onto the wafers using DB method. In the method practiced here, the blade was moved over the flat wafer surface with $\mathrm{H}_{3} \mathrm{PO}_{4}$ film placed in front of it while maintaining the small gap between the blade and the wafer in order to form a thin, uniform film on the wafer. Subsequently, the coated wafers were dried out using an oven at the temperature of $150^{\circ} \mathrm{C}$ for 2 minutes to remove the excess water on the surface. Phosphorus drivein diffusion process was performed at temperatures of 850 , 875,900 and $925^{\circ}$ respectively for 30 minutes in a quartz tube furnace in nitrogen ambient in order to determine an optimum diffusion profile. 


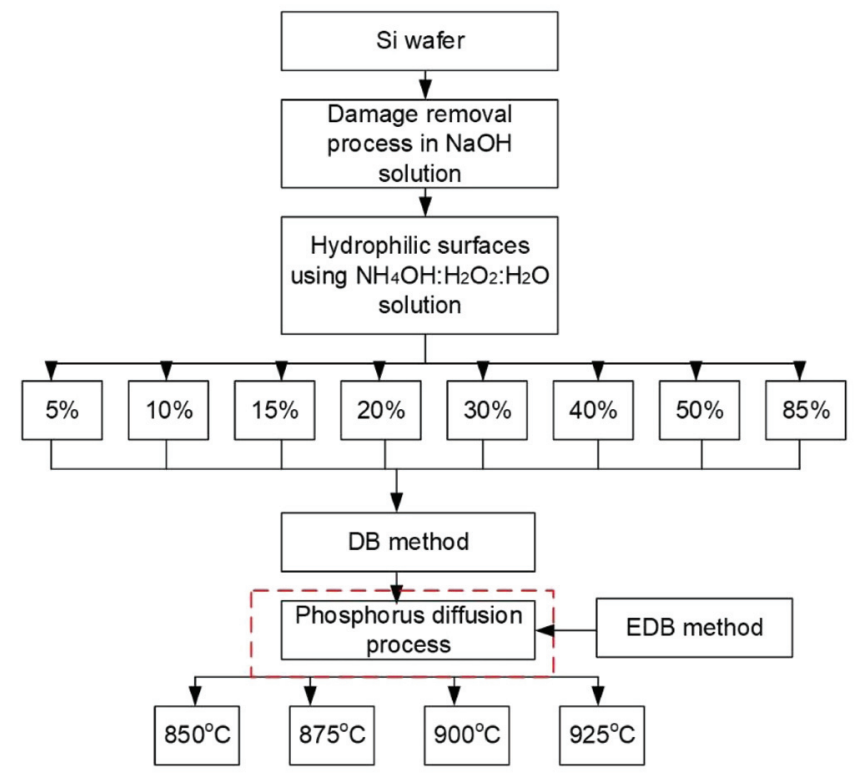

FIGURE 2. Phosphorus diffusion process flow

As part of the diffusion process, another deposition, namely EDB method was investigated. In this EDB method, an un-doped wafer is placed in close proximity to the wafer with deposited $\mathrm{H}_{3} \mathrm{PO}_{4}$ film as shown in Figure 3. In EDB method, the variation of drive-in temperature process was conducted at $850,875,900$ and $925^{\circ} \mathrm{C}$. During the high temperature drivein process, phosphorus emitter was formed in the un-doped wafer through solid source diffusion method. Subsequently, the samples were dipped into hydrofluoric acid: DI water $\left(\mathrm{HF}: \mathrm{H}_{2} \mathrm{O}\right)$ solution with a ratio $1: 1$ by volume to remove the phospho-silicate glass ( $\mathrm{PSG}$ ) layer. For comparison, $\mathrm{POCl}_{3}$ diffusion processes were carried out using a gas-source diffusion furnace at temperatures in range of $850-900^{\circ} \mathrm{C}$. For the emitter characterization, the sheet resistance of the layer was measured by four-point probe method (LUCAS LAB) at five different point across the surface to evaluate uniformity across the Si wafer.

The simulation work was performed using diffusion calculator (DifCad) software. Performance parameters such as sheet resistance and junction depth were identified and their variation as a function of annealing time and temperature were studied. The simulations were carried out in $850-925^{\circ} \mathrm{C}$ temperature range which were similar to the experimental setup. The wafer boron doping concentration was kept constant at for all simulations. Table 1 shows the summary of process parameters used in these simulations.

TABLE 1. Process parameters for phosphorus film coated on silicon wafer

\begin{tabular}{lc}
\hline Solar cell parameters & Values \\
\hline Wafer type & $P$-type \\
Wafer doped & Boron \\
Carrier concentration & $1 \times 10^{15} \mathrm{~cm}^{-3}$ \\
Doping material & Phosphorus \\
Diffusion temperature & $850-925^{\circ} \mathrm{C}$ \\
Time & $1800 \mathrm{sec}$ \\
Doping concentration & \\
\hline
\end{tabular}

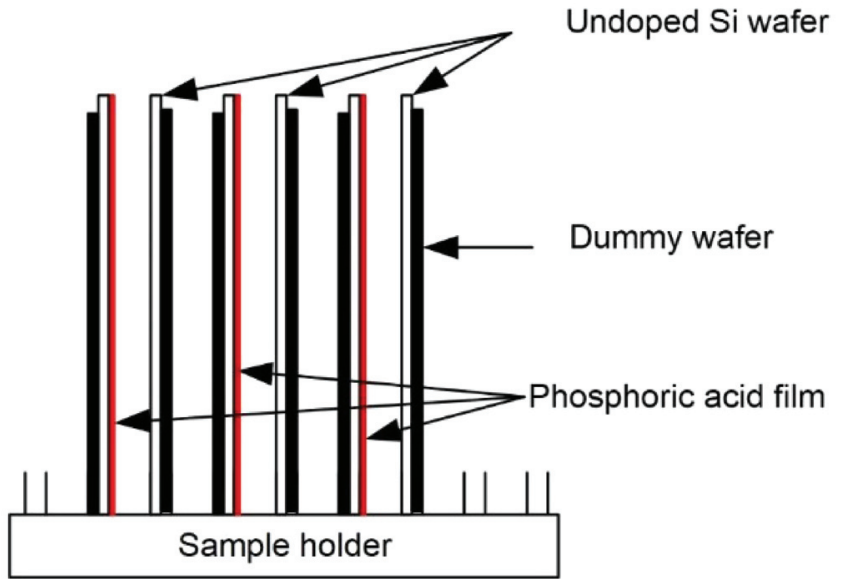

FIGURE 3. Schematic diagram of extension of doctor blade method for phosphorus film deposition

\section{RESULTS AND DISCUSSION}

Figure 4 plots the sheet resistance $\left(R_{\mathrm{sh}}\right)$ as a function of $\mathrm{H}_{3} \mathrm{PO}_{4}$ concentration for both $\mathrm{DB}$ and EDB methods at $T=900^{\circ} \mathrm{C}$ for 30 minutes drive-in diffusion process. From the measurements, it is noted that the sheet resistances over concentrations from $20-85 \%$, for both DB and EDB methods, were not uniform. It is observed that there is significant random variation in resistance values. However, both DB and EDB methods exhibit identical trends in reduction of sheet resistance for $\mathrm{H}_{3} \mathrm{PO}_{4}$ concentrations of $20 \%$ and $40 \%$ and increase at $30 \%$ and $50 \%$. This may be attributed to lack of process controllability, non-uniformity in the $\mathrm{H}_{3} \mathrm{PO}_{4}$ layer thickness, presence of excess phosphorus in high concentration $\mathrm{H}_{3} \mathrm{PO}_{4}$ solutions. Experimental error and diffusion temperature control during deposition process also contribute to fluctuations in both methods. The results reported here are in good agreement with previous work carried out by Kim et al. (2006) where an efficiency of $16.6 \%$ with a shallow emitter with sheet resistance in range of 50 to $100 \Omega /$ sq was demonstrated.

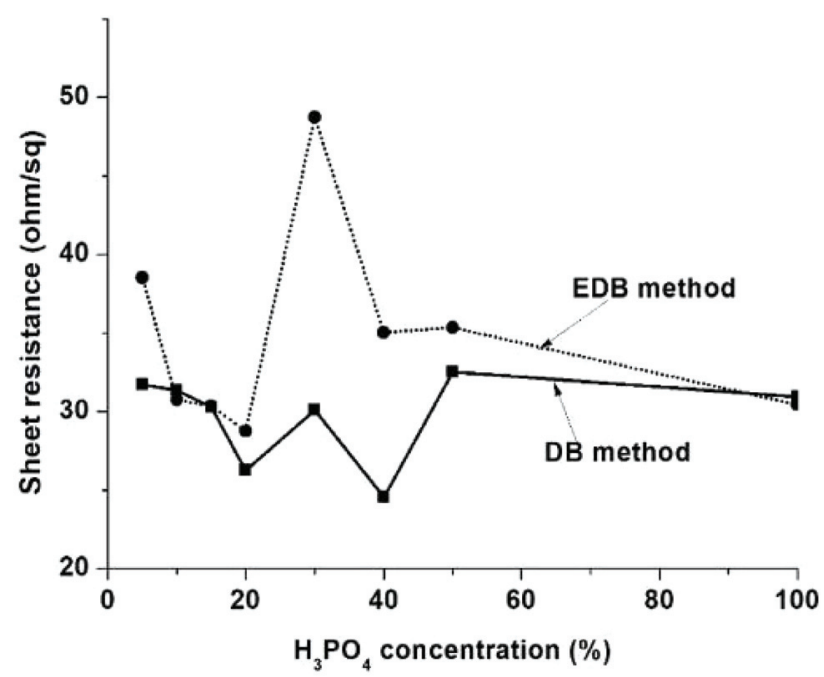

FIGURE 4. Sheet resistance variation as a function of $\mathrm{H}_{3} \mathrm{PO}_{4}$ concentration at drive-in temperature $900^{\circ} \mathrm{C}$ for 30 minutes 
Further analysis was continued with lower concentration of $\mathrm{H}_{3} \mathrm{PO}_{4}$, i.e., 5, 10, 15 and $20 \%$. Investigation of $\mathrm{H}_{3} \mathrm{PO}_{4}$ films at lower concentrations was performed in order to determine minimum quantities of acid required and to prevent undesirable precipitates on the surface. The dopant drive-in was conducted at temperatures of $850,875,900$, and $925^{\circ} \mathrm{C}$. Figure 5 exhibits variation of $R_{\text {sh }}$ at 5 to $20 \%$ of $\mathrm{H}_{3} \mathrm{PO}_{4}$ concentrations, at four different drive-in diffusion temperatures for 30 minutes as deposited by DB method. $R_{\mathrm{sh}}$ values at $T=850^{\circ} \mathrm{C}$ exhibit the same trend with $R_{\mathrm{sh}}$ at $T=925^{\circ} \mathrm{C}$. In contrast, $R_{\mathrm{sh}}$ at $T=875^{\circ} \mathrm{C}$ is contradicted with $T=900^{\circ} \mathrm{C}$. The $R_{\text {sh }}$ of $60-80 \Omega / \mathrm{sq}$ at $T=850^{\circ} \mathrm{C}$ by varying the $\mathrm{H}_{3} \mathrm{PO}_{4}$ concentration. Therefore, shallow-doped emitters were formed at lower temperatures while low (18 to $25 \Omega / \mathrm{sq}$ ) $R_{\text {sh }}$ values were achieved at $T=925^{\circ} \mathrm{C}$. The optimum value of $R_{\text {sh }}^{\text {sh }}$ was obtained at $T=875^{\circ} \mathrm{C}$ with $10 \%$ concentration.

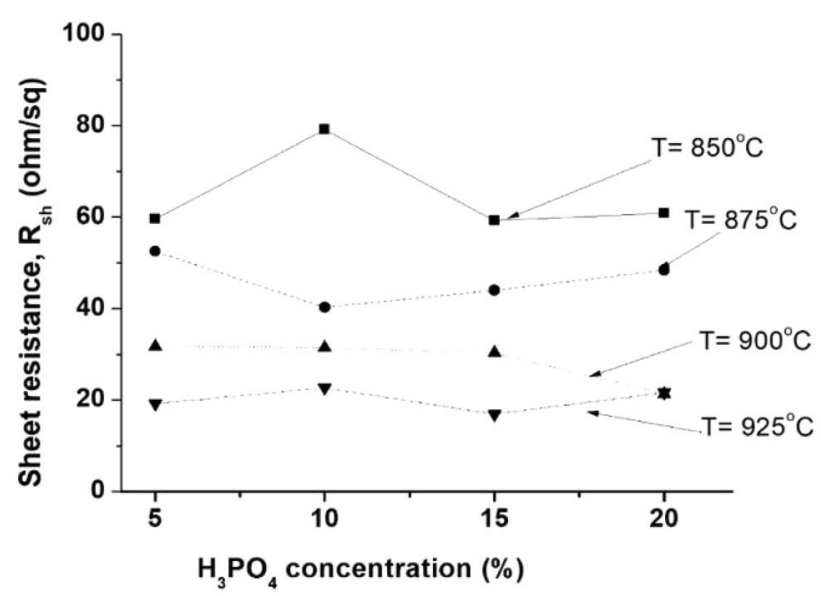

FIGURE 5. Variation of sheet resistance at low $\mathrm{H}_{3} \mathrm{PO}_{4}$ concentrations with four drive-in temperatures for 30 minutes for all films deposited by doctor blade (DB) method

Figure 6 plots the results of $R_{\mathrm{sh}}$ with the same process parameters as shown in Figure 5, but with the EDB method. The highest (in range of 65 to $140 \Omega / \mathrm{sq}$ ) sheet resistances was observed at $T=850^{\circ} \mathrm{C}$. This is attributed to the depletion of phosphorus source. This result is approximately similar with other researchers work on inline diffusion (Kim et. al. 2006). Similarly, at $T=900^{\circ} \mathrm{C}$ and $T=925^{\circ} \mathrm{C}$, the $R_{\text {sh }}$ values were reduced with range of 20 to $38 \Omega /$ sq at 5 to $20 \%$ concentrations. A sheet resistance of $45 \Omega /$ sq was obtained at $T=875^{\circ} \mathrm{C}$ for $10 \%$ concentration. Typically, the optimum phosphorus-doped junction solar cell has $R_{\mathrm{sh}}$ of $30-50 \Omega / \mathrm{sq}$ (Vijay et al. 2005). These results clearly demonstrate that the optimum values are achieved at temperature of $875^{\circ} \mathrm{C}$ for both methods, while $925^{\circ} \mathrm{C}$ is the temperature for heavily doped emitter. With high $R_{\text {sh }}$ (lightly-doped emitter), the probability of shunting across the junction is enhanced due to shallow depth on silicon wafer. With low $R_{\text {sh }}$ (heavily-doped emitter), it exhibits poor blue response due to front surface recombination. Therefore, for lightly-doped shallow emitters, high efficiency solar cell fabrication requires two diffusions: heavily-doped for contacts and light-doped for light sensitive regions. Over all, results reported are in agreement with literature (Lee et al. 2009).

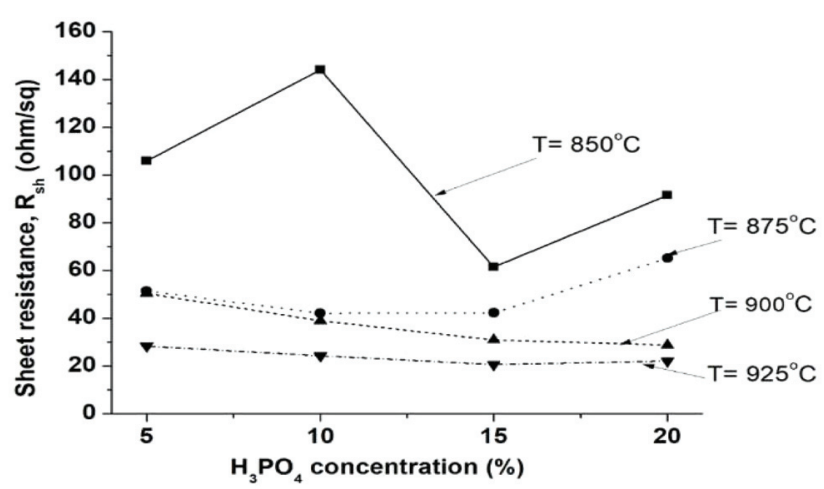

FIGURE 6. Variation of sheet resistance as a function of low $\mathrm{H}_{3} \mathrm{PO}_{4}$ concentrations with four drive-in temperatures for 30 minutes for films deposited by extension of doctor blade (EDB) method

Figure 7 plots experimental data for DB and EDB methods with $10 \% \mathrm{H}_{3} \mathrm{PO}_{4}$ concentration at four different diffusion temperatures namely, $850,875,900$ and $925^{\circ} \mathrm{C}$. For comparison, experiment data performed from $\mathrm{POCl}_{3}$ diffusion method at $850-900^{\circ} \mathrm{C}$ temperature range is also plotted. From the results, it is noted that the sheet resistances from all three methods decreased with the increasing of diffusion temperature. The $R_{\mathrm{sh}}$ of $\mathrm{DB}, \mathrm{EDB}$ and $\mathrm{POCl}_{3}$ methods were 40 , 42 and $47 \Omega /$ sq respectively. The $R_{\mathrm{sh}}$ shows from DB and EDB methods were identical with $\mathrm{POCl}_{3}$ at $T=875^{\circ} \mathrm{C}$. On the other hand, at $T=900^{\circ} \mathrm{C}, R_{\text {sh }}$ values exhibits a big difference between $\mathrm{DB} / \mathrm{EDB}$ and $\mathrm{POCl}_{3}$ techniques which were 35,40 and $6.2 \Omega /$ sq respectively. This is due to the effect of phosphorus dopants supplied during the process. For $\mathrm{POCl}_{3}$ technique, phosphorus source is supplied during the whole process while with the DB/EDB techniques, the source is limited which came from the deposited $\mathrm{H}_{3} \mathrm{PO}_{4}$ film. These methods agreed with the results presented by other researchers (Ahmad et al. 2017; Yadav et al. 2015).

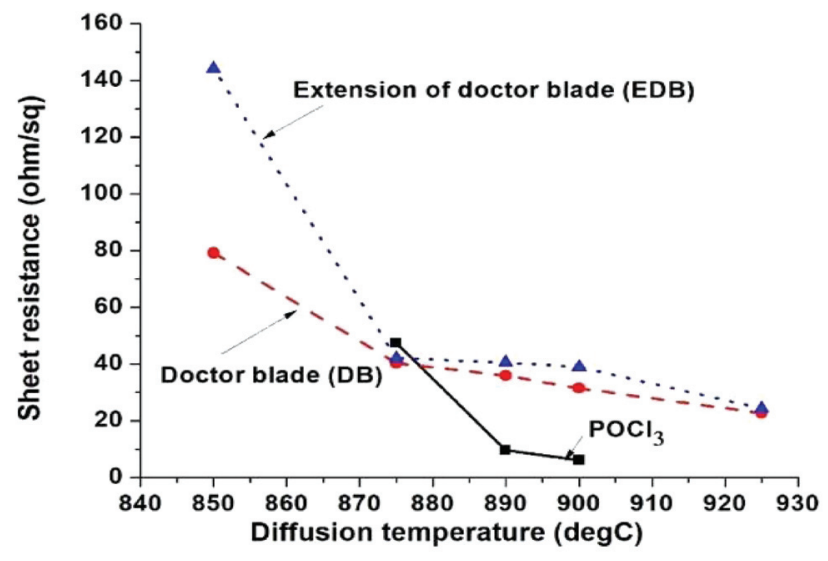

FIGURE 7. Comparison of sheet resistance using $10 \%$ of $\mathrm{H}_{3} \mathrm{PO}_{4}$ concentration for $\mathrm{DB}$ and $\mathrm{EDB}$ methods and $\mathrm{POCl}_{3}$ method 
Figure 8 shows a comparison of sheet resistance with variation of diffusion temperatures by experiment and simulation using DiffCad. By referring to Table 1, doping concentration was varied from $1 \times 10^{17}$ to $5 \times 10^{21} \mathrm{~cm}^{-3}$ with constant value of carrier concentration $=1 \times 10^{15} \mathrm{~cm}^{-3}$.

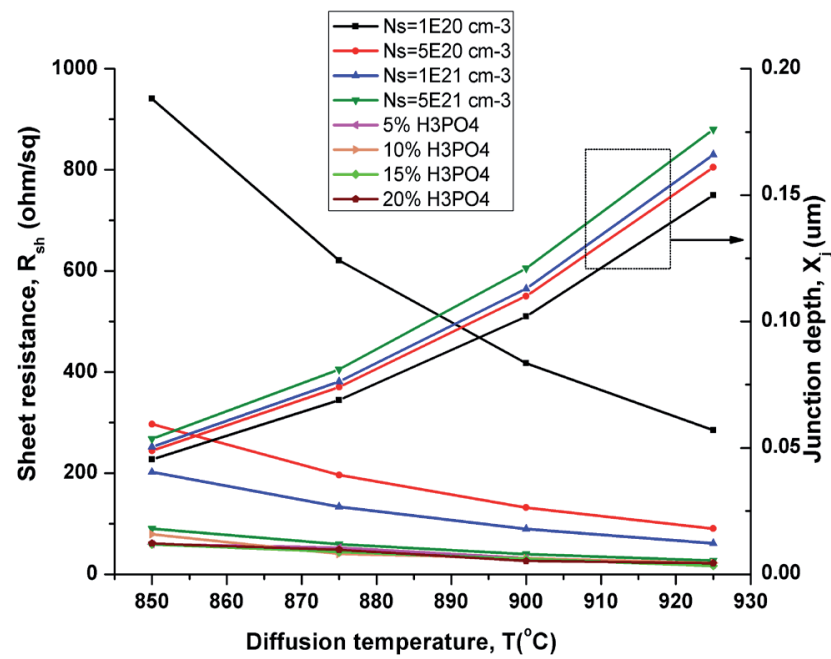

FIGURE 8. Comparison of sheet resistance between simulation and experiment

The result of sheet resistances obtained at lower doping concentrations $\left(1 \times 10^{17}\right.$ to $\left.5 \times 10^{19} \mathrm{~cm}^{-3}\right)$ were very high nearly $\sim 10^{3} \Omega /$ sq at lower temperatures. Otherwise, lower sheet resistances were clearly presented at higher doping concentrations $\left(1 \times 10^{20}\right.$ to $\left.5 \times 10^{21} \mathrm{~cm}^{-3}\right)$. The values reported decreased from 940.42 to $89.21 \Omega / \mathrm{sq}$ at $T=850^{\circ} \mathrm{C}, 621$ to $59.31 \Omega /$ sq at $T=875^{\circ} \mathrm{C}$ and 417.4 to $39.86 \Omega /$ sq at $T=900^{\circ} \mathrm{C}$. From these results, it is observed that the calculated doping concentration of $5 \times 10^{21} \mathrm{~cm}^{-3}$ is in a good agreement with all $\mathrm{H}_{3} \mathrm{PO}_{4}$ concentrations $(5,10,15$ and $20 \%)$ at $T=875^{\circ} \mathrm{C}$ with $R_{\mathrm{sh}}$ values in range of 40 to $59 \Omega / \mathrm{sq}$. Furthermore, junction depth of emitter obtained by simulation at $5 \times 10^{21} \mathrm{~cm}^{-3}$ was presented at $80 \mathrm{~nm}$. This value is used as our reference for junction depth estimation in experimental work.

\section{CONCLUSION}

Fabrication processes on $\mathrm{H}_{3} \mathrm{PO}_{4}$ thin films deposition using DB and EDB method for emitter formation in silicon solar cell has been successfully conducted in terms of diffusion temperature, sheet resistance and $\mathrm{H}_{3} \mathrm{PO}_{4}$ solution concentration. The $\mathrm{H}_{3} \mathrm{PO}_{4}$ with a concentration of $10 \%$ at temperature of $875^{\circ} \mathrm{C}$ has been determined as the best parameter for obtaining the good sheet resistance of $50 \Omega /$ sq. This work demonstrates the diffusion profiles characterization using DifCad simulation tool as our benchmark in doping concentration and junction depth approximation. Therefore, this work can provide as an alternative approach on $n^{+}$emitter solar cell diffusion using $\mathrm{H}_{3} \mathrm{PO}_{4}$ solution as a dopant source due to its non-toxic nature, low cost, and simplicity. Through detailed investigation and analysis, an accurate determination of optimized diffused surfaces has been achieved which enhances their applicability to reduce solar cell manufacturing cost and significantly improve solar cell performance. Further investigations on surface uniformity and diffusion profiles such as time of diffusion will be conducted to improve the emitter formation using $\mathrm{H}_{3} \mathrm{PO}_{4}$ and fabrication of solar cells.

\section{ACKNOWLEDGEMENT}

The authors would like to acknowledge the financial support from the Ministry of Education (MOE) and Universiti Pendidikan Sultan Idris (UPSI). The authors also are grateful to their colleagues from the Solar Energy Research Institute (SERI), Universiti Kebangsaan Malaysia (UKM), for their assistance in sample processing and characterization. Also, thanks to UKM support through Economic Transformation Programme (ETP-2015-001) research grant and Ministry of Science, Technology and Innovation (MOSTI) for Sciencefund Grant (03-01-02-SF1322) .

\section{REFERENCES}

Ahmad, S.M., Cheow, S.L., Ludin, N.A., Sopian, K. \& Zaidi, S.H. 2017. In-depth investigation of spin-on doped solar cells with thermally grown oxide passivation. Results in Physics 7: 2183-2193.

Balaji, N., Park, C., Ju, M., Lee, S., Kim, J., Chung, S., Raja, J. \& Yi, J. 2015. Laser fired local back contact c-Si solar cells using phosphoric acid for back surface field. Journal of Electronic Materials 44(4): 1181-1186.

Basu, P.K., Li, J., Vinodh, S. \& Khanna, A. 2016. Heavy phosphorus tube-diffusion and non-acidic deep chemical etch-back assisted efficiency enhancement of industrial multicrystalline silicon wafer solar cells. RSC Advances 6(42): 35928-35935.

Deng, Y., Peng, E., Shao, Y., Xiao, Z., Dong, Q. \& Huang, J. 2015. Scalable fabrication of efficient organolead trihalide perovskite solar cells with doctor-blade active layers. Energy \& Environmental Science 8(5): 15441550.

Kim, D.S., Hilali, M.M., Rohatgi, A., Nakano, K., Hariharan, A. \& Matthei, K. 2006. Development of a Phosphorus spray diffusion system for low-cost silicon solar cells. Journal of The Electrochemical Society 153(7): A1391A1396.

Kontos, A.I, Kontos, A.G., Tsoukleris, D.S., Bernard, M.C., Spyrelis, N. \& Falaras, P. 2008. Nanostructured $\mathrm{TiO}_{2}$ films for DSSCS prepared by combing doctor-blade and sol-gel method. Journal of Materials Processing Technology 196(1-3): 243-248.

Lee, C.M., Chang, S.P., Chang S.J. \& Wu, C.I. 2013. Fabrication of high-efficiency silicon solar cells by ion implant process. International Journal of Electrochemical Science 8: 7634-7645.

Lee, J., Lakshiminarayan, N., Dhungel, S.K., Kim, K. \& Yi J. 2009. Optimization of fabrication process of highefficiency and low-cost crystalline silicon solar cell for 
industrial applications. Solar Energy Materials \& Solar Cells 93: 256-261.

Moon, I., Gunasekaran, M., Kim, K. Ju, M. Han, S. \& Yi, J. 2009. Investigation on phosphorus doping using $\mathrm{H}_{3} \mathrm{PO}_{4}$ as doping source by simple dip method and its electrical characterization. Surface Engineering 25(2): 151-155.

Ramanathan, S., Das, A. \& Rohatgi, A. 2011. Optimization of phosphoric acid based limited-source-diffusion to obtain high quality emitter for screen printed contacts. Proceeding of $37^{\text {th }}$ IEEE Photovoltaic Specialists Conference 001127-001130.

Sakib, N., \& Ahad,M.A.R. 2018. An Optimized Structure for Enhancing Optical Absorption of Solar Energy in Elliptical GaAs Nanowire Array Solar Cell. Jurnal Kejuruteraan 30(1): 1-6.

Sepeai, S., Cheow, S.L., Zaidi, S.H., Sulaiman, M.Y. \& Sopian, K. 2013. Fabrication and characterization of Al-BSF bifacial solar cell. Proceedings of $39^{\text {th }}$ IEEE Photovoltaic Specialist Conference 2664-2668.

Soin, N. \& Majlis, B.Y. 2006. Development of Design Method and Silicon Corrugated Diaphragm Using KOH An-isotropic Etching. Jurnal Kejuruteraan 18: 147160.

Sopian, K., Cheow, S.L. \& Zaidi, S.H. 2017. An overview of crystalline silicon solar cell technology: past, present and future. AIP Conference Proceedings: $4^{\text {th }}$ International Conference on the Advancement of Materials and nanotechnology 1877(1): 020004-1-020004-11.

Vijay, K., Nakayashiki, K., Hilali, M. \& Rohatgi, A. 2005. Implementation of a homogenous high sheet resistance emitter in multicrystalline silicon solar cells. Proceedings of $31^{\text {st }}$ IEEE Photovoltaic Specialist Conference 959962.

Yang, X., Müller, R., Xu, L., Bi, Q., Weber, K., Franklin, E. $\&$ Benick, J. 2015. Ion-implanted laser-annealed $p^{+}$and $n^{+}$regions: a potential solution for industrially feasible back-contact solar cells. Proceedings of IEEE Journal of Photovoltaics 5(1): 87-93.

Yadav, A., Singh, G., Nekovei, R. \& Jeyakumar, R. 2015. $\mathrm{C}$-Si solar cells formed from spin-on phosphoric acid and boric acid. Renewable Energy. 80: 80-84.

*Zon Fazlila Mohd Ahir

Department of Engineering Technology,

Faculty of Technical \& Vocational (FTV),

Universiti Pendidikan Sultan Idris,

43600 Tanjung Malim, Perak, Malaysia

Suhaila Sepeai and Saleem H. Zaidi.

Solar Energy Research Institute (SERI),

Universiti Kebangsaan Malaysia,

43600 Bangi, Malaysia.

*Corresponding author;

email: fazlilamohdahir@gmail.com_

Received date: $17^{\text {th }}$ May 2018

Accepted date: $17^{\text {th }}$ July 2018

Online First date: $1^{\text {st }}$ October 2018

Published date: $30^{\text {th }}$ November 2018 